культуры. Научно-технический бюллетень Всероссийского НИИ масличных культур, 2015. Выл. 2 (162). С. 87-92.

3. Бабич А.О., Бабич-Побережна А.А. Прогнозований вплив глобальних змін клімату на виробництво зернових і зернобобових культур. Засуха, суховій і пилова буря в період глобальних змін клімату. Монографія. Т. 1. Вінниця:ТОВ «Видавництво-друкарня ДІЛО», 2014. С. 399-408.

4. Бабич А.О., Бабич-Побережна А.А. Вплив глобальних і локальних змін клімату на урожайність сільськогосподарських культур в Україні. Засуха, суховій і пилова буря в період глобальних змін клімату. Монографія. Т. 2. Вінниця:ТОВ «Видавництво-друкарня ДІЛО», 2014. C. $162-266$.

5. Державна служба

статистики

України.

URL: http://www.ukrstat.gov.ua/.

DOI https://doi.org/10.30525/978-9934-26-111-4-46

\title{
ВПЛИВ ЗМІНИ КЛІМАТУ В УКРАЇНІ НА СІЛЬСЬКЕ ГОСПОДАРСТВО
}

\author{
Закорчевна Н. Б. \\ кандидат економічних наук, \\ завідувачка кафедри водних екосистем і біоресурсів \\ Державний заклад «Державна екологічна академія післядипломної \\ освіти та управління» \\ Демидюк Ю. С. \\ аспірантка \\ Державний заклад «Державна екологічна академія післядипломної \\ освіти та управління» \\ м. Київ, Украӥна
}

Зміну клімату за останні 30 років називають «антропогенною». Людство впродовж свого існування втручалося в природу і продовжує це робити - вирубує ліси та бездумно розорює землі, порушуючи режим вологості та вітровий режим планети, а також у великих обсягах спалює викопні палива, що $є$ головним джерелом викидів парникових газів. За песимістичними прогнозами, подальше бездумне руйнування 
навколишнього середовища людством може спричинити незворотну зміну клімату.

Наразі клімат України у тренді глобального потепління, воно охопило всю територію нашої країни, а швидкість підвищення температури повітря навіть дещо випереджає середньосвітову. Головна характеристика зміни клімату (основний параметр) - це зміна середньої річної температури повітря нижнього шару атмосфери (на висоті 1 метр над поверхнею). Вона визначається за даними вимірювань 163-х метеорологічних станцій України, які мають безперервний період спостережень від 65 до 140 років. Згідно досліджень цього параметру сучасний клімат України характеризується нерівномірним по території потеплінням. За розрахунками кліматологів середня швидкість потепління в Україні складає близько $0,4{ }^{\circ} \mathrm{C}$ за 10 років. Отже, за умови збереження таких темпів потепління вже через 30 років середня річна температура може підвищитися ще на $1-1,5^{\circ} \mathrm{C}$.

Підвищення температури у холодний період (листопад-березень) складає в середньому $1,3^{\circ} \mathrm{C}$, у теплий (квітень-жовтень) $-1,1^{\circ} \mathrm{C}$. Позитивна аномалія (відхилення температури повітря від норми) по всій території країни у період 1989-2020 рр. була найбільшою за всю історію інструментальних спостережень за погодою. Сьогодні кліматичні умови південного Полісся і північного Лісостепу за сумою ефективних температур стали такими, які були характерні для зони Степу 30 років тому.

У 2020 році Україна опинилася на порозі значного дефіциту наявних водних ресурсів для життєзабезпечення населення та економіки у зв'язку з гідрологічною посухою цього року. За даними Українського гідрометцентру з вересня 2019 року по травень 2020 року на території України випало 153 мм опадів при нормі 211 мм. Тобто за цей час кількість води і опадів зменшилась на 35 трильйонів літрів, це близько 10 Київських водосховищ. 70\% потреб країни забезпечує басейн Дніпра, і до початку травня річка отримала лише половину кліматичної норми опадів. Травневі дощі не виправили ситуацію, так як дощі що пройшли у Київській області «підняли» рівень води всього на один см. Саме таке явище і називається гідрологічною посухою.

За останні 20 років посухи реєструвалися майже щорічно i охоплювали вони більше половини території України, що дає підстави відносити посухи до явища природи, яке має істотний вплив i відповідно вимог СС, мають розроблятися Плани управління посухами для окремих річкових басейнів. 
Офіційна цифра розораності території України 54\%, але науковці вважають, що цей показник сягає $60 \%$, що є неприпустимим. Посуха i маловоддя, не дивлячись на дощі і навіть зливи, стануть невід'ємною характеристикою нашої території, так як антропогенне навантаження на неї перевищило екологічно допустиме. Грунти деградують, втрачають природний склад і тепер вода 3 поверхні не просочується як раніше, поповнюючи грунтові води найближчого до поверхні підземного горизонту. Іншими словами, зменшилось, а на багатьох територіях практично зникло, інфільтраційне живлення підземних водоносних горизонтів. Необгрунтоване осушення боліт, вирубування лісу, видобуток торфу зневоднило річки Полісся, яке відносилося до зони достатнього зволоження. Все це загрожує Україні зникненням i так невеликої зони достатнього зволоження (Полісся та західний Лісостеп) і переходом цієї зони до нестійкого та недостатнього зволоження.

За даними Національної академії аграрних наук України, в останні десятиліття межі природно-кліматичних зон країни фактично змістилися на 100-150 км на північ.
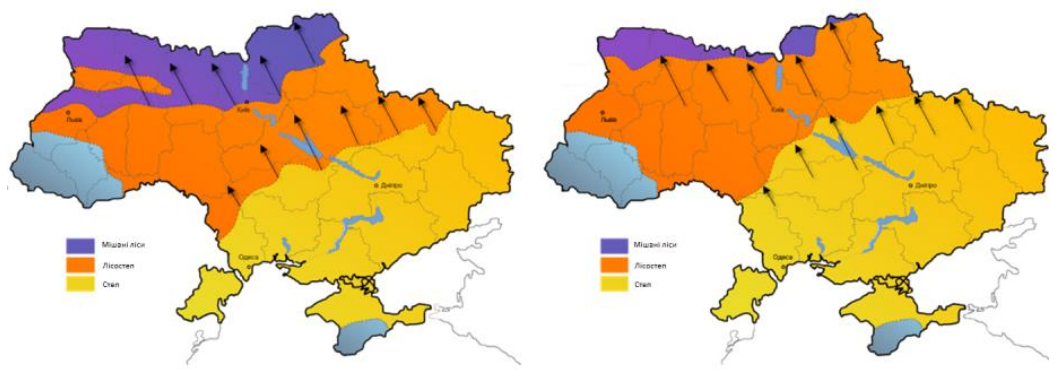

Зміни клімату, які супроводжуються погіршенням умов природного вологозабезпечення, зумовлюють необхідність у штучному поліпшенні водного режиму грунту під час вирощування сільськогосподарських культур і мінімізації впливу кліматичних змін на ведення агровиробництва. На середньострокову (до 2050 року) та довгострокову перспективи (до 2100 року) прогнозується висока ймовірність зменшення площ орних земель із достатнім зволоженням до 5,5 1,8 млн. га. А зростання сумарного випаровування спричинить подальше зневоднення території України та зменшення доступних для використання запасів поверхневих і підземних вод. 
Одним із основних засобів мінімізації впливу сучасних кліматичних змін на водозабезпеченість території України є використання наявного потенціалу дренажних систем та їхньої водорегулюючої здатності, що $\epsilon$ невикористаним ресурсом підвищення врожайності і сталого ведення сільськогосподарського виробництва. Разом із тим, в умовах зростаючого дефіциту водних ресурсів забезпечення оптимальних параметрів регулювання водного режиму на осушуваних землях можливе завдяки підвищенню водозабезпеченості меліоративних систем, що може бути досягнуто завдяки акумулюючій здатності меліорованих територій.

Наслідки зміни клімату для сільського господарства країни в цілому та для фермерських господарств зокрема досить складні та неоднозначні. Певною мірою позитивним наслідком зміни клімату $є$ суттєве потепління зимових місяців, відповідно, і зменшення ризиків вимерзання озимих культур. Зимовий період скоротився майже на місяць і це створює умови для більш ранньої сівби ярих культур. Період активної вегетації сільськогосподарських культур вже подовжився на 10 днів і більше. Це додаткові можливості для вирощування усіх видів теплолюбних сільськогосподарських культур. Вже майже немає територій із обмеженими тепловими ресурсами для вирощування теплолюбних культур (кукурудзи, сої). Водночас, стрімке та надмірне накопичення тепла скорочує вегетаційний період, сприяє передчасному достиганню різних культур і може призвести до зменшення врожайності.

У південній частині України підвищення температури та подовження вегетаційного періоду дозволять фермерам вирощувати по два врожаї деяких культур за умови зрошення.

Площі під посівами технічних культур в Україні збільшилися за останні 30 років у 13,9 рази за рахунок розширення посівних площ соняшника, сої та ріпака. Посівні площі соняшнику зросли з 16,8 до 278,2 тис. га (у 16,6 рази), сої - з 1,3 до 70,4 тис. га (у 54,1 рази), ріпака - 3 7,8 до 11,3 тис. га (у 1,4 рази). Проте площі посівів цукрового буряка зменшилися за цей же період 3 119,5 до 0,8 тис. га (майже у 150 разів), однак його врожайність збільшилася майже у 2 рази.

Як видно з наступного рисунку, від 1998 року в зоні Полісся значно зросли посівні площі кукурудзи та соняшнику, а саме - на 98843 та 126963 га відповідно, тоді як для степової зони ці значення дорівнюють 361551 і 473044 га (за даними Інституту космічних досліджень НАН України та Державного Космічного Агентства України) 


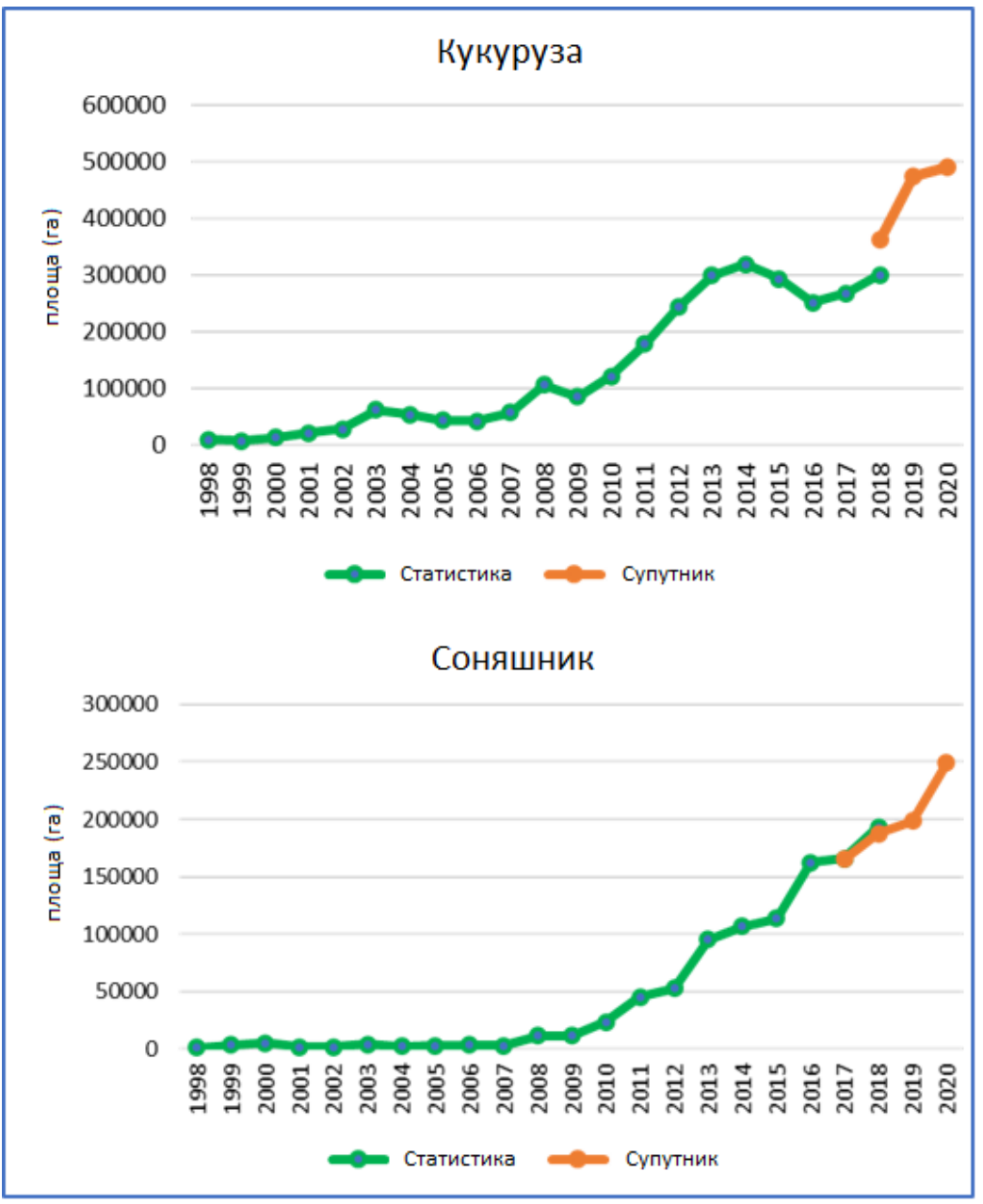

Сільське господарство, яке потерпає від зміни клімату, одночасно $є$ джерелом викидів парникових газів, а отже однією із причин цієї зміни, адже тваринництво і рослинництво пов'язані з викидами вуглекислого газу, метану і оксиду азоту. Відповідно до звітів про викиди, які уряди країн регулярно надають Секретаріату Рамкової конвенції ООН зі зміни клімату, на сільське господарство припадає приблизно $15 \%$ від світового обсягу викидів парникових газів. Обсяг викидів залежить від типу грунтів, вологості, температури і системи обробітку грунту. Метан 
утворюється в результаті переробки мікробами в анаеробних умовах органічної речовини в травному тракті жуйних та інших тварин (кишкова ферментація), при зберіганні органічних добрив, а також при всіх перетворювальних процесах в умовах браку кисню у повітрі.

2018 року частка викидів парникових газів від агропромисловості в Україні сягнула $12 \%$ і наразі демонструє найбільшу тенденцію до зростання серед усіх секторів. Вже до 2030 року викиди від сектору можуть збільшитися на 64\%. Поміж усіх видів агровиробництва найбільший вуглецевий слід має тваринництво. Викиди від нього становлять близько $16 \%$ від усіх у світі, що порівняно з викидами від транспорту та промисловості. Щоб зменшити викиди, бізнес в країні повинен дотримуватися світових стандартів поводження з тваринами та відходами, до того ж вони мають значний потенціал для відновлюваної енергетики.

Україні необхідно зменшити розорюваність території, площа ріллі в Україні може бути зменшена на 8-10 млн га, до 22-25 замість 32 млн га, за рахунок залуження, підвищення лісистості, і відповідно покращення водоакумулюючих i водотранспортуючих здатностей водозбірних територій річкових басейнів. Україна має поступово відмовлятися від оранки як основного способу обробітки грунту, тому що такий спосіб обробітку формує підвищену здатність викидів СО2 і сприяє прискореному нарощуванню температурного режиму що спричиняє підвищення сумарного випаровування.

\section{Література:}

1. Чи загрожує Україні водний дефіцит? Висновки експертів. URL: http://dea.edu.ua/article/chi_zagrozhu_ukraini_vodnii_deficit_ visnovki_ekspertiv.

2. Стратегія зрошення та дренажу в Україні на період до 2030 року. Схвалено Кабінетом Міністрів України, 2019. № 688-р.

3. Вплив сучасних кліматичних змін на водні ресурси та сільськогосподарське виробництво / Ромащенко М.I. та ін. // Меліорація і водне господарство. 2020. № 1. С. 5-22.

4. Як зміни клімату впливають на площі основних сільськогосподарських культур в Україні. URL: https://www.nas.gov.ua/ UA/Messages/news/Pages/View.aspx?MessageID=7830.

5. Як сільське господарство впливає на клімат і чому невдовзі від цього страждатиме. URL: https://zn.ua/ukr/ECOLOGY/agrovirobnictvovs-zmina-klimatu-hto-kogo-346513_.html. 